\section{ANTAGONISMO, LEGITIMIDAD Y PODER POLÍTICO EN CÓRDOBA, 1877-1880}

de Laura Cucchi, Bahía Blanca, Editorial de la Universidad Nacional del Sur, 2015, 312 págs.

RAQUEL BRESSAN

Instituto de Ciencias - Universidad Nacional de General Sarmiento - CONICET
En los últimos años se ha llevado adelante una profunda renovación en el campo de la historia política y bajo este espíritu se han analizado las dinámicas, las prácticas y las formas de participación que tuvieron lugar durante las etapas de construcción y de consolidación del Estado argentino durante la segunda mitad del siglo XIX. Uno de los temas que forman parte de esta renovación y que constituye un clivaje entre una y otra etapa, refiere al rol de las disputas por el poder de las organizaciones partidarias en la dinámica política. Precisamente, Antagonismo, legitimidad y poder politico en Córdoba, $1877-$ 1880, reconstruye cuáles eran las formas en que se tramitaba el antagonismo y el conflicto político a partir del análisis de las prácticas de los sectores políticos cordobeses para procesar la oposición y el desacuerdo, durante los últimos años de la década de 1870 .

Un aspecto relevante del enfoque que presenta este libro, es su distancia de las interpretaciones que conciben a la conflictividad y a la inestabilidad de esta etapa como resultado del carácter faccioso de las agrupaciones políticas, el cual resaltaba los orígenes meramente coyunturales y de ambición de poder de tales enfrentamientos. La autora considera que el concepto de faccionalismo ha constituido «una explicación en alguna medida circular y totalizadora del accionar político del siglo XIX y ha contribuido a clausurar muchos interrogantes sobre las formas de acción y concepción de la política específicas del período». Por lo tanto, a partir de un minucioso análisis de un extenso y diverso corpus de fuentes primarias y secundarias, Laura Cucchi explora y reconstruye en los seis capítulos que componen el libro, las formas en que los grupos políticos provinciales presentaron y resolvieron sus conflictos y los mecanismos que utilizaron para zanjar sus enfrentamientos en la prensa, en el terreno electoral y a través de las luchas armadas. 
El primer capítulo, «La política cordobesa en la década de 1870», recupera la situación política provincial de este período. En sus páginas se registran los principales espacios de intervención constituidos por los clubes políticos, la legislatura, la guardia nacional, la prensa y las universidades. Asimismo, en este capítulo se pone de relieve cómo las líneas de tensión entre la Iglesia y el Estado formaron parte de los conflictos entre los actores políticos.

En el segundo capítulo, "Un nuevo elenco político», se abordan las condiciones del ascenso del autonomismo en Córdoba y cómo se despliega la estrategia del gobierno para consolidar su posición a nivel local. Cucchi señala que la principal herramienta fue la completa reorganización de la estructura de autoridad provincial, a partir del nombramiento de nuevas figuras en los ámbitos institucionales como los ministerios, las municipalidades y las jefaturas políticas. La reestructuración de la guardia nacional y el uso de la maquinaria electoral reforzaron esta medida con la ocupación por parte del oficialismo de espacios, como la legislatura, donde previamente se concentraba la mayoría opositora.

El tercer capítulo, «Sacristanes contra racionalistas. Un nuevo frente de disputas», da cuenta de los conflictos entre el Estado provincial y la Iglesia a partir de las intenciones del gobierno de Antonio
Del Viso de incorporar bajo la jurisdicción estatal ámbitos - como la educación y el registro de personas- que estaban hasta ese momento bajo sujeción de la Iglesia. Asimismo, se analiza cómo las controversias entre los sectores laicos y católicos fueron capitalizadas y explotadas, tanto por el gobierno como por los opositores.

El cuarto capítulo, «La organización partidaria y el problema de la representación política», avanza hacia los últimos años de la década de 1870 y se centra en las dinámicas partidarias establecidas a partir de la definición de las candidaturas presidenciales. En primer lugar, se analiza el contexto de incertidumbre y de permanente reorganización del mapa electoral ocasionado por la política de conciliación que buscó implementar Nicolás Avellaneda. En segundo lugar, se despliega cómo se fueron trazando las coordenadas de ese mapa a partir de acciones de alcance nacional y local. Así, a la vez que se crearon comisiones para establecer comunicaciones más directas y fluidas entre los partidos, el propio gobernador de Del Viso buscó estrechar las relaciones con los gobernadores de las otras provincias a través de la correspondencia, el uso de la prensa y de encuentros personales para definir al candidato por el autonomismo. A nivel local, en cambio, el autonomismo puso en juego la estructura de poder construida en los dos años de gobierno, la cual permitió una amplia instalación de 
los clubes políticos y un fluido manejo de la maquinaria electoral. En tercer lugar, la autora se detiene en el análisis de la prensa, herramienta fundamental para alcanzar los objetivos electorales, y reconstruye cómo se definieron las representaciones del antagonismo político existentes en la provincia desde los artículos impresos en sus páginas. Mientras la oposición se definía como representante de la voluntad del pueblo -entendida como unánime- y como heredera del partido liberal tradicional, a la vez que reflotaba el enfrentamiento contra la barbarie del federalismo, los autonomistas recuperaron la identidad federal como sinónimo de la autonomía provincial y frente al concepto totalitarista de "pueblo" apelaron al de representación de la mayoría y asignaron un valor positivo a las divisiones entre los partidos como legitimo derecho de opinión.

El quinto capítulo, «En la marcha de nuestros gobiernos republicanos», abarca el periodo de agitación política comprendido entre la elección de electores de noviembre de 1879 y la protesta de los conciliados en febrero de 1880. Aquí, la autora explora los diferentes espacios de poder de cada partido y los mecanismos de reclutamiento y movilización puestos en juego durante esta coyuntura. Así, se analizan las dinámicas y los recursos utilizados por cada uno, los cuales ni eran homogéneos ni estaban monopolizados por el oficialismo. En este sentido, la oposición equilibró, a través de su mayor control de las dependencias nacionales en la provincia como el Ferrocarril del Norte y las universidades, el dominio del autonomismo de las dependencias estatales provinciales. Asimismo, la prensa constituyó una herramienta clave en la disputa interpartidaria y, luego de la derrota del nacionalismo en las urnas, fue el principal instrumento para convocar y legitimar la acción armada. Un aspecto relevante del análisis de estos recursos está conformado por la utilización de las leyes de regulación de libertad de imprenta para limitar el avance de los nacionalistas en este terreno. De esta forma, Cucchi da cuenta de las prácticas del autonomismo para trasladar la lucha de la arena estrictamente periodística a la institucional.

El último capítulo, «Disputas por las palabras», analiza los diferentes usos del concepto «revolución» para presentar y dirimir las disputas políticas. En tanto los nacionalistas concebían a la acción armada como forma de intervención política dentro de los significados tradicionales presentes a lo largo del siglo XIX -la lucha legítima contra la tiranía y el despotismo-, Cucchi resalta que los autonomistas, en cambio, produjeron un desplazamiento de este significado. Así, desde distintos ámbitos, las voces autonomistas proclamaron una nueva concepción que asociaba a la revolución con la transformación económica y social, el anhelado «progre- 
so» que sería posible en base al orden y al cumplimiento de la Constitución.

Antagonismo, legitimidad y poder politico en Córdoba, 1877-1880, forma parte del conjunto de investigaciones que en los últimos años ha modificado su escala de enfoque para pensar la historia nacional desde los espacios regionales. La obra indaga en el potencial de análisis que ofrecen los procesos particulares de las provincias, para comprender las características de la dinámica política argentina de la segunda mitad del siglo XIX. Asimismo, la obra de Laura Cucchi, ofrece claras y significativas respuestas sobre las formas de acción y de concepción de la política de los integrantes de los partidos políticos cordobeses de este período. En suma, al reponer cómo surgen y comienzan a definirse los lineamientos y prácticas políticas que se consolidarían luego durante el roquismo, el libro constituye una importante contribución para comprender una etapa crítica y poco explorada de la historia política argentina. 